\title{
REFORMULASI WACANA KEADILAN SAHABAT
}

\author{
Adnan \\ Dosen Fakultas Ushuluddin UIN Sunan Gunung Djati Bandung \\ J1. AH. Nasution No. 105, Bandung, Indonesia \\ E-Mail: Adnanbz99@gmail.com
}

\begin{abstract}
One of hadith discourse is the doctrine of claim that the companions of the Prophet are the group is considered to know the group's most religious doctrines in the original form. The companions also transmit all riwayah to the next generation. A transmission path can only be accepted if they have the criteria of justice. The problem is, will this criterion of justice was applied to the companions of the Prophet?

This article will to review and discuss back discourse companions justice ('al-Sahabah) is. Rational arguments and historical completing this study to re-open nature of this issue and look at its implications for the study of modern traditions.
\end{abstract}

Keywords: Ahli Sunnah; Companion; Hadis; Justice; Muhaditsun

\begin{abstract}
Abstrak
Dalam wacana kajian hadis salah satu doktrin yang dibahas adalah klaim bahwa sahabat Nabi merupakan kelompok yang paling dianggap mengetahui doktrin agama dalam bentuknya yang orisinal. Sahabat nabi juga yang mentransmisikan awal periwayatan kepada generasi berikutnya. Suatu jalur periwayatan hanya dapat diterima bila memenuhi kriteria keadilan periwayatnya. Masalahnya, akankah kriteria ini keadilan itu diterapkan terhadap sahabat nabi ? Tulisan pada artikel ini hendak mengulas dan mendiskusikan kembali wacana keadilan sahabat ('adalah alsahabah) ini. Argumentasi rasional dan historis melengkapi kajian ini untuk membuka kembali hakikat persoalan ini dan melihat implikasinya bagi kajian hadis modern.
\end{abstract}

Kata Kunci: Hadis; Muhadisun, Sahabat; Keadilan; Ahli Sunnah.

\section{A. PENDAHULUAN}

Tidak dapat disangkal lagi dalam rangka pembahasan ilmu hadis, peranan para sahabat amatlah besar. Hal itu logis, karena tidaklah mungkin berita-berita tentang Nabi dan ajarannya itu akan sampai pada generasi berikutnya, bahkan AI-Qur'an sekalipun tidak akan pernah lestari hingga generasi sesudah sahabat, merekalah yang sangat berjasa dalam memelihara. menghapal, mencatat hingga lestari dan monumental hingga saat ini. Namun, dalam masalah penyelidikan terhadap para perawi merupakan kewajiban dalam rangka memelihara kemurnian hadits Nabi yang didasarkan pada kaidah ajaran Islam. Al Qur'an memberikan inspirasi kepada para ulama agar penyelidikan dalam rangka memelihara kermurnian Hadits tersebut dilakukan, misalnya dalam Surat A1-Hujurat Allah berfirman yang artinya " Hai orang -

* Corresponding Author.Tel: +12-3456789

E-mail: author@author.com orang yang beriman jika datang kepadanmu orang fasik membawa suatu berita maka periksalah dengan teliti . . . ( Q. S AlHujurat : 6 )

Ayat tersebut mengandung maksud bahwa berita yang datang dari seorang yang meragukan, mencurigakan, apalagi tidak dapat dipercaya, harus diteliti terlebih dahulu, sehingga bisa jelas mana informasi yang benar dan mana informasi yang salah, terlebih-lebih berita yang dinyatakannya itu sebagai hadits Nahi Muhammad SAW.

Dalam makalah ini penulis akan menjelaskan tentang 'adalah sahabat, karena 'adalah (Keadilan) atau kejujuran atau kejujuran perawi atau sanad hadits merupakan problematika yang tidak dapat diabaikan dalam menilai derajat suatu hadits, dan nilai tersebut sangat urgen dalam penerimaan suatu hadits. Sebagaimana kita ketahui periwayatan hadis baru dianggap sempurna jika pada diri perawi terdapat sifat 'adalah dan dhabit/tsiqoh. Demikian pula 
halnya mengenai karakteristik sahabat Nabi dalam periwayaran hadis haruslah mereka itu memiliki sifat 'adalah.

\section{B. PEMBAHASAN}

\section{Pengertian Sahabat}

Sahabat menurut makna etimologisnya berasal dari bahasa Arab "Shahabiy " yang diambil dari Kata "Shuhbah". Kata ini digunakan untuk mengartikan setiap orang yang bersahabat dengan orang lain, baik lama maupun sebentar ${ }^{1}$ Mahmud Thahhan menggartikan kata sahabat adalah isim masdar berarti berteman atau berkawan. ${ }^{2}$

Kata Sahabat menurut makna terminologinya ada beberapa macam :

1. Mahmud Thahhan mengatakan: "Sahabat lalah orang yang bertemu dengan Nabi SAW dalam keadaan Islam dan mati secara Islam pula sekalipun pernah murtad". 3

2. Fachtur Rahman mengatakan: "Sahabat ialah orang yang berteman dan hidup bersama Rasulullah SAW minimal setahun lamanya.$^{4}$

3. Menurut para Muhaditsin memberikan definisi sahabat dengan ungkapan : sahabat ialah orang yang pernah berjumpa dengan Nabi SAW beriman kepadanya dan mati sebagai muslim, ${ }^{5}$. Sadang ulama Ushuliyyin mengatakan :

"Sahabat ialah orang yang lama bergaul dengan Rosulullah SAW dan sering menghadiri pertemuan bersama beliau dalam proses belajar untuk memperolah petunjuk (Ilmu pengetahuan $)^{6}$

Beberapa hadis di atas dapat dilihat, bahwa pendapat para Ushuliyyin kelihatannya lebih ketat dalam menetapkan kriteria apakah seseorang itu termasuk sahabat afaui tidak, karena hal tersebut erat kaitannya dengan periwayatan dan

${ }^{1}$ Hasyim Ma'ruf Husni, Dirosat Fil Hadis Wal Muhadissin (Darr al- Ta'aruf 1978). 67.

${ }^{2}$ Mahmud Thahhan, Taysir Musthalah A1-Hadis (Tsaqofah Islamiyah 1997). 231.

${ }^{3}$ Thahhan. 231

${ }^{4}$ Fathurohman, Musthalahatul Hadis (Al-Ma'arif 1981). 246

${ }^{5}$ Shubhi Shalih, Ulumul Al-Hadis Wamas Alatuhu (: Dar afi-Walayin 1977). 352.

${ }^{6}$ Mustafa Amin Ibrahim Al-Tazi, Muhadharat Fi Ulum A1-Hadis Jamia 'ah (al-Azhar 1971). penerimaan hadits dari Nabi. Mereka memberikan kriteria tambahan bukan hanya lama bergaul dengan Nabi, tetapi juga sering tidaknya ikut pengaijan atau belajar secara langsung kepada Nabi. Sedangkan Jumhur A1-Muhaditsin kelihatannnya agak longgar dalam memberikan definisi tentang sahahat, meraka hanya mensyaratkan pernah berjumpa dangan Nabi, serta bergaul secara wajar dalam keadaan islam dam iman.

Nampaknya terdapat banyak definisi tentang arti sahabat, namun yang lebih masyhur dikalangan umat Islam adalah apa yang didefinisikan oleh ulama Muhaditsin di atas, yaitu orang yang pernah berjumpa dengan Nabi SAW, beriman kepadanya dan mati dalam keadaan Muslim.

Adapun untuk mengetahui seseorang itu dikatakan sahabat dapat diketahui dengan cara :

1. Berita Mutawatir, yaitu berita yang diriwayatkan oleh sekian orang sahabat yang keadilannya diyakini, mustahil berita itu bohong atau mereka sepakat berbohong, seperti diberitakan sepuluh sahabat yang dijanjikan masuk surga. Mereka itu adalah : Khulafa al-Rasyiddin, Sa'ad Ibn Abi Waqas, Said ibn Zaid, Thalhah Ibn Ubaidillah, Zubair ibn Awwam, Abd. Al-Rahman ibn Auf dan Abi Ubaidah 'Amir ibn jarrah.

2. Khabat Masyhur, berita tersebut masyhur tersiar dan terkenal sehingga tidak diragukan lagi, bahwa perawi itu sahabat Nabi. Mereka itu antara lain Dhimam ibn Tsa'1abah dan Akasah ibn Muhashshin.

3. Khabar dari sahabat yang terkenal seperti perkataan Abu Musa al Asy'ari dalam kesaksiannya mengatakan, bahwa Hummah ibn Abi Hummah al-Dausi adalah sahabat Nabi.

4. Pengakuan seseorang bahwa dia adalah sahabat Nabi setelah diketahui 'adalahnya. ${ }^{7}$

Beberapa cara di atas dapat ditempuh untuk menatapkan seseorang itu dapat dikatakan sahabat atau bukan. Data dan

\footnotetext{
${ }^{7}$ Muhammad Ajjaj A1- Khatib, Al- Sunnah Qobla Al- Tadwin (Maktabah Wahhab 1963).
} 
beritanya harus benar-benar meyakinkan dan tidak mengandung keraguan.

\section{Argumentasi Alquran tentang Sahabat}

Pandangan di atas didasarkan atas teksteks al-Qurean dan hadis Nabi. Dalam alQur"ean, penegasan keadilan sahabat terdapat antara lain:

1.QS al-Fath; 18 :

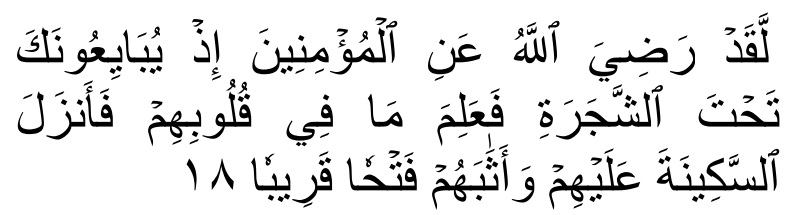

Sesungguhnya Allah telah ridha terhadap orang-orang mukmin ketika mereka berjanji setia kepadamu di bawah pohon, maka Allah mengetahui apa yang ada dalam hati mereka lalu menurunkan ketenangan atas mereka dan memberi balasan kepada mereka dengan kemenangan yang dekat (waktunya).( QS alFath; 18 ).

2. QS al-Anfal: 74.

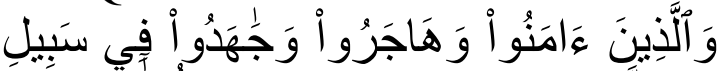

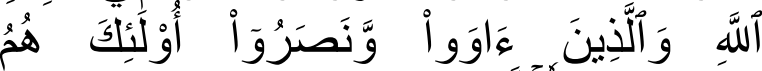

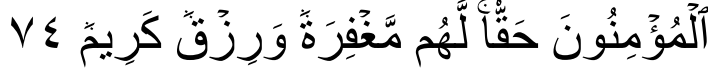

Dan orang-orang yang beriman dan berhijrah serta berjihad pada jalan Allah, dan orang-orang yang memberi tempat kediaman dan memberi pertolongan (kepada orang-orang muhajirin), mereka itulah orang-orang yang benar-benar beriman. Mereka memperoleh ampunan dan rezeki (nikmat) yang mulia. (QS al-Anfal: 74.)

3.QS al-Hasyr: 8-9.

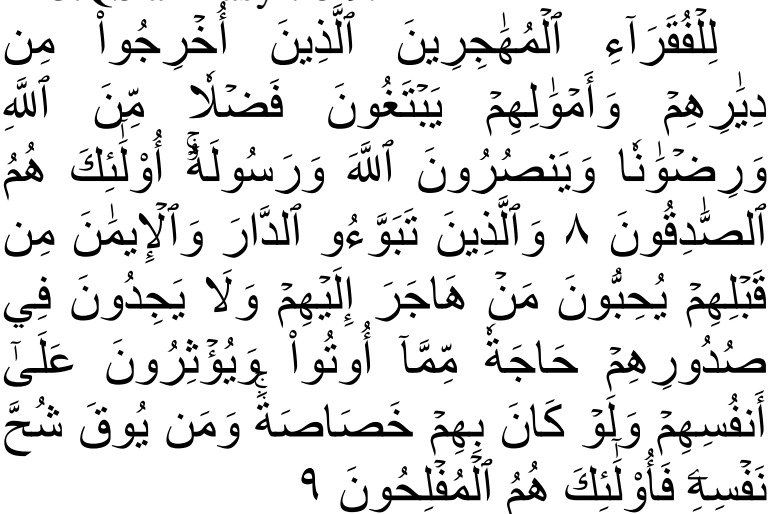

8. (Juga) bagi orang fakir yang berhijrah yang diusir dari kampung halaman dan dari harta benda mereka (karena) mencari karunia dari Allah dan keridhaan-Nya dan mereka menolong Allah dan Rasul-Nya. Mereka itulah orang-orang yang benar (9.) Dan orang-orang yang telah menempati kota Madinah dan telah beriman (Anshor) sebelum (kedatangan) mereka (Muhajirin), mereka (Anshor) 'mencintai' orang yang berhijrah kepada mereka (Muhajirin). Dan mereka (Anshor) tiada menaruh keinginan dalam hati mereka terhadap apa-apa yang diberikan kepada mereka (Muhajirin); dan mereka mengutamakan (orang-orang Muhajirin), atas diri mereka sendiri, sekalipun mereka dalam kesusahan. Dan siapa yang dipelihara dari kekikiran dirinya, mereka itulah orang orang yang beruntun.( QS al-Hasyr: 8-9).

\section{Thabaqat Sahabat}

Peringkat para sahabat Nabi SAW dikenal dengan istalah Thabaqat al- sahabat. Ulama berbeda pendapat dalam menentukan peringkat para sahabat, ada yang menentukan jumlahnya lima paringkat dan ada yang menentukan sebelas peringkat. Yang menentukan Iima peringkat sahabat Nabi SAW urutannya sebagai berikut :

1. Sahabat Nabi yang lebih dahulu masuk Islam dar kalompok orang tua seperti $\mathrm{Abu}$ Bakar al-Shiddiq ra.

2. Sahabat dari kelompok anak-anak seperti Ali ibn Abi Thalib ra.

3. Sahabat dari kelompok wanita seperti Siti Khodijah ra.

4. Sahabat dari kelompok Mawalal seperti Zayd.

5. Sahabat dari budak belian ( hamba sahaya ) sepeti bilal ra. ${ }^{8}$

Kriteria Thabaqat di atas diambl berdasarkan kelompok yang paling awal masuk Islam dari sahabat Nabi SAW baik dari golongan orang tua, anak-anak, wanita, mawalah dan hamba sahaya.

\footnotetext{
${ }^{8}$ al-Hakim al-Naisaburi, Ma'rifat Ulum Al-Hadis
} (Maktabah al-Mutanabbi). 22-24. 
Adapun Imam al-Hakim al-Naisabur membagi para sanahat Nabi SAW itu ke dalam sebelas (11) peringkat, urutannnya sebagai berikut:

1. Sahabat yang masuk Islam di Mekah seperti Abu Bakar, Umar, Ustman, Ali dan lain-lain.

2. Sahabat yang bergabung dalam Dar alNadwah, yang ketika Umar menyatakan keislamannya mereka membawanya kepada Rosullullah lalu membai'atnya.

3. Sahabat yang turut berhijrah ke Habsyi.

4. Sahabat yang mambai'at Nabi SAW di Aqobat al-Ula.

5. Sahabat yang membai'at Nabi pada Aqobah ke dua yang kebanyakan orangorang anshor.

6. Orang-orang Muhajirin pertama yang menemui Rnsulullah selagi beliau di Quba, sebalum memasuki Madinah.

7. Sahabat yang termasuk dalam pasukan badar pertama.

8. Sahabat yang ikut berhijrah kesuatu tempat antara Badar dan Hudaibiyah.

9. Kelompok Bai'atur Ridwan.

10. Sahabat yang ikut hijrah antara alHudaibiyah dan al-Fath seperti Khalid ibn al-Walid, Amru ibn al-Ash, Abu Khurairah dan lain lain. ${ }^{9}$

11. Orang yang islam pada waktu futh Makkah.

Para remaja dan anak-anak yang sempat melihat Rosululaah SAW, pada waktu penaklukan Mekah dam Haji wada' atau di tempat lain, Penjelasan pengelompokan sahabat tersebut bukan hanya dilihat dari segi sering tidaknya berkumpul dengan Nabi, atau banyak Tidaknya meriwayatkan hadis dari Nabi Tapi dilihat siapa yang paling lebih dahulu masuk Islam, siapa yang lebih dahulu hijrah, siapa yang ikut perang Badar, dan ikut perjanjian Hudaibiyah, bahkan sampai kepada remaja dan anak-anak yang pernah melihah Nabi SAW.

\footnotetext{
${ }^{9}$ Fathurohman. 254-255
}

\section{Keadilan (adalah) Para Sahabat}

Kata "Adalah" berasal dari kata "al-Adl" yang berarti adil, kebenaran dan tidak berlaku zhalim. ${ }^{10}$ Jika dikaitkan dengan hadits berarti riwayat hadits itu harus diterima lawan "al-adl" adalah al-zhulm atau zhalim. ${ }^{11}$ yakni tidak adil berarti riwayat yang disampaikannya tidak dapat diterima.

Shubhi Shalih, mengartika adalah ialah sifat otang yang Tetap pendirian dalam agama, selamat dari segala bentuk kefasikkan dan kerusakkan, ${ }^{12}$ Khotin al-Baghdadi mengartikan " Adalah" atau "al-Adl" ialah orang yang terkenal ketaatannya menjalankan perintah Allah menjauhi sejala larangannnya. menjauhkan diri dari perbuatan keji, memelihara hak dan kewajiban dalam segala tindakan dan pergaulan, menjaga lidah dari kata-kata yang dapat merusak agama, dan orang yang memiliki sifat-sifat tersebut maka ia disebut orang adil dalam agama dan dikenal benar dalam pembicaraannya. ${ }^{13}$

Walaupun terdapat beberapa pengertian tentang 'adalah namun dalam pengertian tersebut tidaklah saling bertentangan, tetapi saling menguatkan dan menyempurnakan antara satu dengan yang lain. Dari pengeretian-pengertian tersebut dapat disimpulkan 'adalah ialah memelihara agama, menjauhi segala larangan, menjaga diri dari berbuat bohong dan kesalahan, serta selain menjaga kehormatan ( Muru'ah ). Orang yang mempunyai sifat di atas disebut orang adil dan riwayatnya dapat diterima dan dipercaya.

Ada beberapa versi untuk menilai keadilan para sahabat. Versi pertama persi Jumhur mengatakan semua sahabat adalah adil. ${ }^{14}$ Ini sesuai dengan kaidah " al-Shabah Kulluhum udul" Versi kedua bahwa semua sahabat boleh diuji keadilannya, kebanyakan mereka adalah dari golongan ulama Muta'akhirin seperti Muhammad Abduh.

\footnotetext{
${ }^{10}$ muhammad idris Al-marbawi, Kamus Idris AlMarbawi (mustafa babil halaby). 10.

11 Lois Ma'luf, Al-Munjid (Al-Maktabah alsyarkiah 1986). 491.

${ }^{12}$ Shalih. 129.

${ }^{13}$ Shalih. 129.

${ }^{14}$ Thahhan. 199
} 
Rasyid Ridho, Muhammad abu Royah flan lain-lain. Menurut mereka sahahat itu manusia blasa yang boleh jadi alfa. ${ }^{15}$ Versi ketiga yaitu persi Mu'tazilah mereka berpandapat, bahwa semua sahabat itu adil, kecuali orang memerangi dan membunuh Ali, mereka adalah Fasik, riwayat dan kesaksian meraka tidak dapat diterima. ${ }^{16}$

Adapun kriteria yang digunakan untuk menatapkan keadilan rawi adalah berdasarkan

a. Popularitas keutamaan dan kemuliaannnya dikalangan ulama hadis.

b. Penilaian dari para kritikus rawi yang berisi pengungkapan-pengungkapan terhadap kelebihan dam kekurangan yang ada pada Rawi tersebut.

c. Penerapan kaidah al Jarh wa-at-ta'dil yang dipakai ketika para kritikus rawi tidak sepakat dalam menilai seorang rawi. ${ }^{17}$

Dengan beberapa pernyataan rentang penilain terhadap rawi hadis keadilannya sangat diperlukan kesaksian para ulama. Diantara ayat ayat Al-Qur'an yang dijadikan dalil bagi ulama yang berpendapat bahwa sahabat itu adil adalah :

a. Surat At-Taubah ayat 100 :

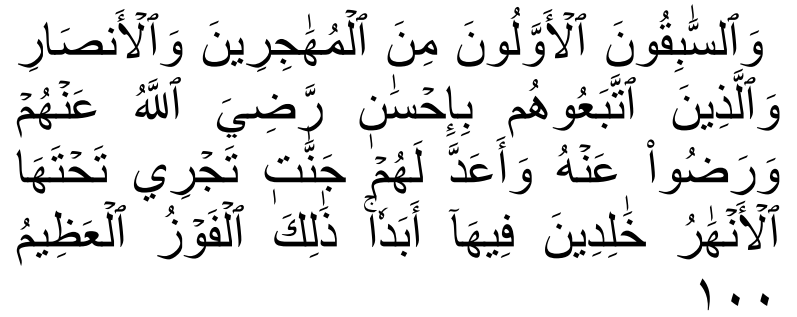

100. Orang-orang yang terdahulu lagi yang pertama-tama (masuk Islam) dari golongan muhajirin dan anshar dan orang-orang yang mengikuti mereka dengan baik, Allah ridha kepada mereka dan merekapun ridha kepada Allah dan Allah menyediakan bagi mereka surga-surga yang mengalir sungai-sungai di dalamnya selama-lamanya. Mereka kekal di dalamnya. Itulah kemenangan yang besar

\footnotetext{
${ }^{15}$ M Zuhri, Hadis Nabi (Tiara Wacana 1977). 132.

16 Al-Suyuthi, No Title (Madinah: Maktabah alIlmiyah, 1972). 214.

${ }_{17}$ M Husain Yusuf, Pengembangan Pemikiran Terhadap Hadis (LPPI 1996). 31.
}

b. QS. Al-Anfal :74.

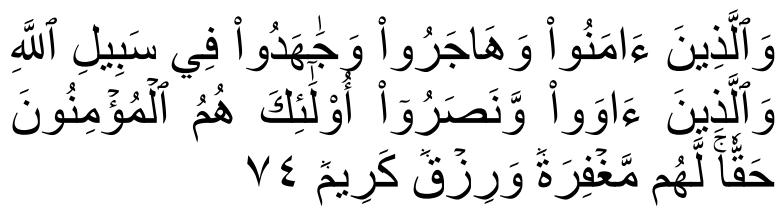

Dan orang-orang yang beriman dan berhijrah serta berjihad pada jalan Allah, dan orang-orang yang memberi tempat kediaman dan memberi pertolongan (kepada orang-orang muhajirin), mereka itulah orang-orang yang benar-benar beriman. Mereka memperoleh ampunan dan rezeki (nikmat) yang mulia. (QS. Al-Anfal :74).

c. QS. Al-Fat :18.

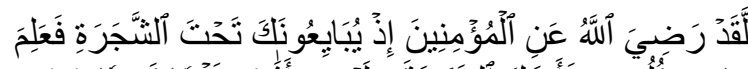

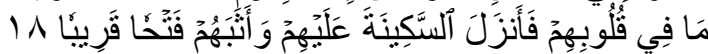

Sesungguhnya Allah telah ridha terhadap orang-orang mukmin ketika mereka berjanji setia kepadamu di bawah pohon, maka Allah mengetahui apa yang ada dalam hati mereka lalu menurunkan ketenangan atas mereka dan memberi balasan kepada mereka dengan kemenangan yang dekat (waktunya). (QS. Al-Fath :18).

Ayat-ayat tersebut menunjukkan keutamaan dan kemuliaan para sahabat Nabi SAW, mulai dari orang yang ikut bersama Rasulullah SAW menyampaikan da'wah, sampai kepada perperangan dan janji setia Hudaibiyah dan menggambarkan pula kedudukan orang yang ikut hijrah dan berjihad di jalan Allah.

Ayat-ayat Tersebut menjadi dalil tentang ke adalahan mereka.

\section{SIMPULAN}

Dari uraian makalah tentang " Adalah" sahahat dapat disimpulkan sebagai berikut :

1. Sahabat ialah orang yang pernah berjumpa dengan Nabi Muhammad SAW atau lama bergaul dengan beliau, bahkan sampai akhir hayatnya beagama Islam, sedangkan para Ushuliyyin dengan menanbah yaitu mengikuti pengajian dari Nabi Muhammad SAW.

2. Sahabat memiliki kriteria adil dalam arti taat menjalankan aturan-aturan agama, 
memelihara diri dari perbuatan yang tidak terpuji seperti berbohong, serta selalu menjaga kehormatan.

3. Secara umum semua sahabat bersifat adil, tetapi secara khusus ada sahabat yang cacat ke-'adalahannya, ada yang menyebutkan nama Abdullah bin Saba, Amru lbn al-Ash bahkan utsman bin alAffan.

\section{DAFTAR PUSTAKA}

al-Hakim al-Naisaburi, Ma'rifat Ulum AlHadis (Maktabah al-Mutanabbi)

Al-marbawi muhammad idris, Kamus Idris Al-Marbawi (mustafa babil halaby)

Al-Suyuthi, No Title (Maktabah alIlmiyah 1972)

Al-Tazi MAI, Muhadharat Fi Ulum A1Hadis Jamia' 'ah (al-Azhar 1971)
Fathurohman, Musthalahatul Hadis (AlMa'arif 1981)

Husni HM, Dirosat Fil Hadis Wal Muhadissin (Darr al- Ta'aruf 1978)

Khatib MAA-, Al- Sunnah Qobla AlTadwin (Maktabah Wahhab 1963)

Ma'luf L, Al-Munjid (Al-Maktabah alsyarkiah 1986)

Shalih S, Ulumul Al-Hadis Wamas Alatuhu (: Dar afi-Walayin 1977)

Thahhan M, Taysir Musthalah A1-Hadis (Tsaqofah Islamiyah 1997)

Yusuf MH, Pengembangan Pemikiran Terhadap Hadis (LPPI 1996)

Zuhri M, Hadis Nabi (Tiara Wacana 1977) 